\title{
愛知県渥美半島の沿岸低地で見出された江戸時代の 津波起源と推定されたイベント堆積物
}

\author{
阿部朋 弥 ${ }^{1, a} \cdot$ 白 井 正 明*2
}

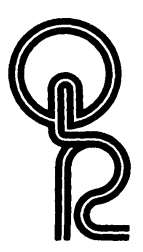

過去から現在までに度重なる津波の被害を受けてきた愛知県渥美半島太平洋岸の沿岸低地を対 象に, 堆積学的手法を用いて, イベント堆積物の特徴を検討した。採取された 3 本の柱状コアと トレンチ断面の樑度 $30 \mathrm{~cm}$ 付近に, 平常時の堆積物とは異なる特徴を持つ層厚 $1 \sim 4 \mathrm{~cm}$ の砂層 が観察された。䇥法および沈降管法による粒度分析， 円磨度解析から，この砂層の主な供給源は 海浜であることが示唆された．海浜砂の運搬距離，海浜砂と河川砂の混合，津波と高潮との水理 学的特徴の違いなどをもとに推定されるイベントの性質と, ${ }^{14} \mathrm{C}$ 年代を参考にした歴史記録の記 述との比較から, この砂層は江戸時代の歴史地震に伴う津波堆積物であると推定される.

キーワード：津波堆積物，粒度分析，円磨度解析，歴史記録

\section{I. は じめ に}

東海地方の沿岸部は南海トラフで発生する海溝型地震 に伴う津波の襲来を繰り返し受けており，その被害や規 模は主に歴史記録から検討されてきた(飯田, 1985 ; 渡 辺, 1998 ; 宇佐美, 2003). しかし, 歴史記録だけでは, 対象とする期間の長さや，情報の質・量ともに限界があ る(小松原ほか, 2006a ; Komatsubara and Fujiwara, 2007). そのため, 東海地方においては, 静岡県浜名湖周 辺 (熊谷, 1999 ; 高田ほか, 2002 ; 小松原ほか, 2006b ; Komatsubara et al., 2008) や三重県志島低地 (小松原 · 岡村, 2007 ; 藤野ほか, 2008) などにおいて, 堆積物記 録から古津波の発生間隔や規模が推定されてきた。 これ らの研究では, 南海トラフで発生する津波の発生間隔の 復元に主な焦点が当てられてきた. しかし, 将来の津波 リスクを想定するためには, 発生間隔だけではなく, 古 津波の規模および挙動の復元も重要である. そのために は，これまで多く行われてきた堆積物記録と歴史記録の どちらか一方による古津波の復元ではなく, 堆積物記録 と歴史記録の両面から，古津波の規模および挙動を検討 する必要がある.
本研究では, 愛知県渥美半島太平洋岸の沿岸低地で堆 積物調査を実施し, 堆積物の記載, 笠法・沈降管法によ る粒度分析, 円磨度解析, ${ }^{14} \mathrm{C}$ 年代測定を行うことに加 え, 歴史記録に関しても検討した，その結果，江戸時代 の地震に伴う津波によって形成された可能性が高い砂層 を認めたので，ここに報告する.

\section{II. 地形的特徵と堆積物の記載}

\section{1. 地形的特徵}

渥美半島は浜名湖の約 $20 \mathrm{~km}$ 西側から西南西方向に 伸び, 東西約 $35 \mathrm{~km}$, 南北 $6 \sim 9 \mathrm{~km}$ の形状を持つ. 西 南西方向に連続する丘陵が半島の骨格をなし, 天竜川や 豊川起源の砂鿬から構成される段丘および低地が, その 丘陵の間を埋めるように広がる. 半島の南部は太平 洋 (遠州灘) に，北部は内湾である三河湾に面している.

調査地域は渥美半島の太平洋岸のほぼ中央に位置して いる(図 1)。本地域には, 海洋酸素同位体ステージ (MIS) 5 相当の海成段丘と推定されている福江面 (杉山, 1991) が開析されて形成された谷底平野が広がる. 現在, 本地域を流れる池尻川および精進川は赤羽根漁港に流出 しているが, 1951 (昭和 26) 年以前には漁港は存在せず,

\section{2 年 9 月 3 日受付. 2013 年 2 月 2 日受理.}

${ }^{*} 1$ 名古屋大学大学院環境学研究科地理学講座 \%464-8601 名古屋市千種区不老町 D2-1.

*2 首都大学東京大学院都市環境科学研究科地理環境科学域 ₹192-0937 八王子市南大沢 1-1.

*a Corresponding author : abe.tomoya@a.mbox.nagoya-u.ac.jp 
河口付近には海浜や海岸林が分布していた.

\section{2. 堆積物の記載}

堆積物調查は, 2009 年 4 月から 10 月にかけて実施さ れた。調査では, 谷底平野上の休耕田 (標高 $1.8 \mathrm{~m}$ ) で
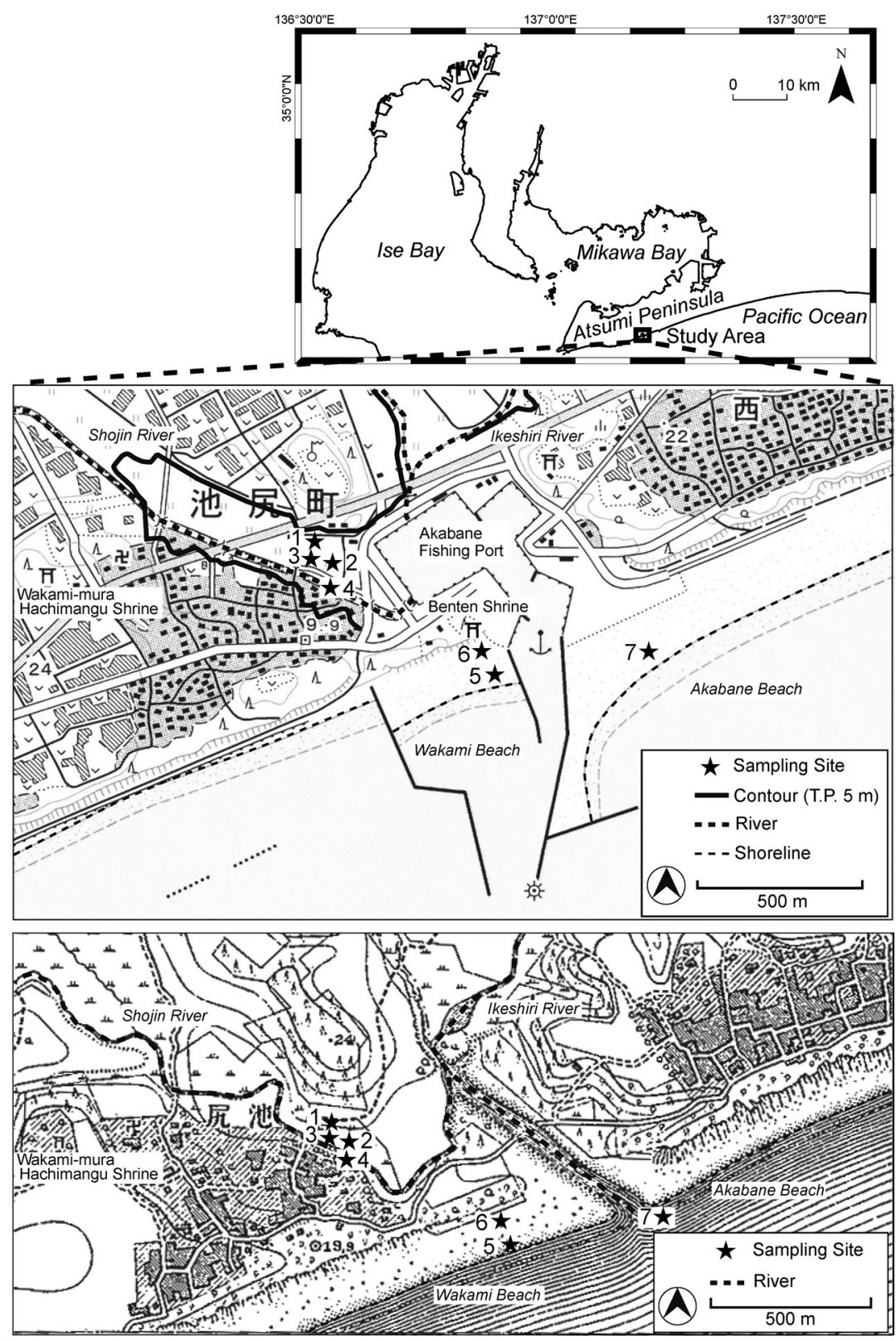

図 1 調查地域周辺の現在 (上) および赤羽根漁港建設以前 (下) の地形と試料採取地点の位置 基図には国土地理院 2009 年発行 2.5 万分の 1 地形図「野田」, 陸軍部測量局 1893 年発行 2 万 分の 1 地形図「福江村」を使用.

Fig. 1 Map showing the current study area (upper) and sediment sampling sites and old topography (lower) The base map is the $1: 25,000$ topographic map of "Noda" published by the Geospatial Information Authority of Japan in 2009 and the $1: 20,000$ topographic map of "Fukue-mura" published in 1893. 
3 本の柱状コア (地点 $1 ， 2 ， 3$ )を採取し (図 2), さらに 地点 3 ではトレンチ (東西 $1 \mathrm{~m} \times$ 南北 $1 \mathrm{~m} \times$ 深さ $1 \mathrm{~m}$ ) 掘 削を実施し, 堆積物の記載, 各種分析試料の採取を行っ た. また, 休耕田近くの精進川で河床堆積物（地点 4)を, 南側の海浜の前浜 (地点 5,7 ) および後浜 (地点 6) で海 浜砂をそれぞれ採取した。

休耕田上の地点 1 3 の地表から深度 22〜24 cm まで は, イネ科の植物の根を多く含み, 粒径 $1 \sim 3 \mathrm{~cm}$ の角 砂が散在している耕作土である。この層は, 地点 3 の トレンチ断面 (図 3) において上下層の混合の痕跡が観 察される。

(1) 地点 1

地表面から深度 $22 \mathrm{~cm}$ までは耕作土, 深度 $22 \sim 44 \mathrm{~cm}$ は主に砂質シルトからなる. 深度 $29 \sim 30 \mathrm{~cm}$ には, チャー 卜礫混じりの細粒砂層 (S1-1) が挟まれる (図 2).

(2) 地点 2
地表面から深度 $23 \mathrm{~cm}$ までは耕作土, 深度 $23 \sim 71 \mathrm{~cm}$ は主に砂質シルトからなる. 深度 28～31 cm にチャー 卜啋混じりの正級化を示す極細粒砂〜細粒砂層 (S2-1) が, 深度 37〜 59 cm に極細粒砂〜細粒砂層 (S2-2) がそ れぞれ観察される (図 2).S2-2 砂層は, 砂質シルト層 および植物片を多く含む有機シル卜層を挟む 5 枚のサ ブユニットに分かれている. 最下位のサブユニット（深 度 $55 \sim 59 \mathrm{~cm}$ ）は正級化しており, 粒径 0.2 1 cm の チャートの亜角礫〜亜円鿬を含む. 深度 $64 \sim 66 \mathrm{~cm}$ に は, 細粒砂層 (S2-3) が挟まれる.

\section{（3）地点 3 (トレンチ観察結果を含む）}

柱状コアでは, 地表面から梁度 $24 \mathrm{~cm}$ までは耕作土 が見られる. 深度 24〜100 cm は主に砂質シルトからな る. 深度 30〜34 cm にチャート礫混じりの正級化する 極細粒砂〜細粒砂層 (S3-1) が観察される (図 2). 砂層 基底部上には粒径 $0.2 \sim 2 \mathrm{~cm}$ の泥岩やチャートの亜角

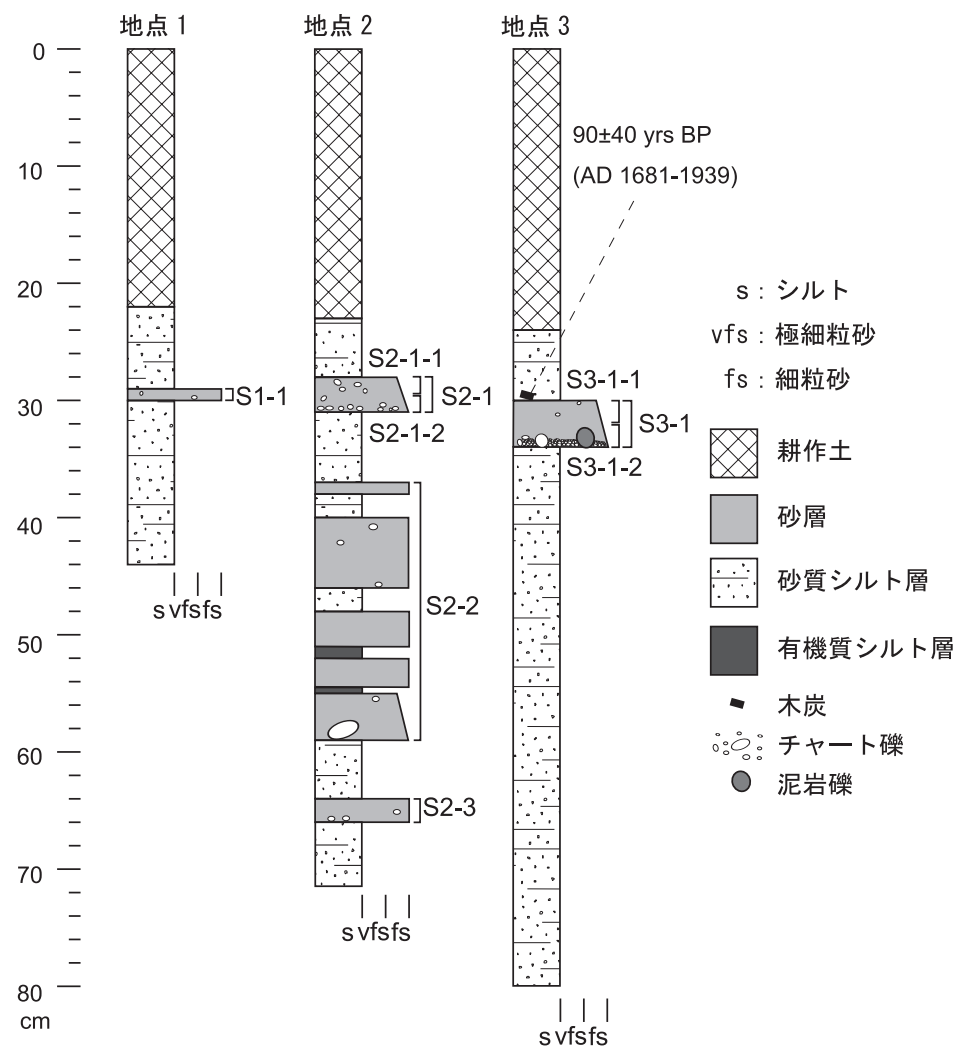

図 2 各掘削地点で得られたコアの柱状図 地点 3 についてはトレンチ断面観察も統合してある.

Fig. 2 Columnar section of sediment core at each drilling site Observation of a test trench is integrated to site 3 column. 
礫〜円礫が載る。トレンチ断面では，明瞭な侵食基底面 を持つ砂層の下部に粗粒砂〜極粗粒砂サイズのチャート 岩片が濃集する (図 3)。砂層の上部は弱い平行ラミナを 呈し，正級化する極細粒砂～細粒砂層が見られる.

\section{III. 研 究 手 法}

\section{1. 粒度分 析}

地点 1 3 の深度 $30 \mathrm{~cm}$ 付近で観察された砂層 ( $\mathrm{S} 1$ 1, S2-1, S3-1) および海浜砂 (地点 5〜7), 河床堆積 物（地点 4）について, 篩法を用いて粒度分析を行った. 笮法では，比較的厚い砂層 (S2-1，S3-1) については上 部と下部 (S2-1-1 と S2-1-2, および S3-1-1 と S3-1-2) に分割して分析を行った. 一方, 沈降管法では, トレン チでも観察され，追加試料を得ることができた S3-1 砂 層と, 地点 5〜7 の海浜砂について分析を行った. 試料 は, 過酸化水素水により試料中の有機物を分解し, $63 \mu \mathrm{m}$ $(4 \phi)$ の篮を用いて水洗により泥分を洗い流した．その 後, 篩法では開き目 $500 \mu \mathrm{m}(1 \phi), 250 \mu \mathrm{m}(2 \phi), 125$ $\mu \mathrm{m}(3 \phi)$ の穊を用いて穊い分けを行った．沈降管法で は，成瀬 (2005) による沈降管天科法 (計測区間：-1〜 $4 \phi$ ，計測間隔： $0.2 \phi)$ にもとづき分析を行った.

\section{2. 円磨度解析}

柱状試料中の砂層と周辺の堆積物の円磨度を比較する ため, 地点 2 の砂層 (S2-1), 海浜砂 (地点 5 7) と河床
堆積物 (地点 4) について円磨度解析を行った．粒径が 極細粒砂ないし粗粒シルトより細かくなるとほとんど機 械的な円磨 (水や風による運搬過程中の円磨)を受けず, 化学的な溶解の影響が強くなる (公文・立石編，1998). そのため，1２申の中粒砂サイズの粒子を用いて測定 を行った，測定鉱物は海浜砂に多く含まれ，化学的な溶 解の影響を受けにくい石英粒子とした. 1〜2 2 に篩い分 けした試料を，四分法により粒子数が 100〜150 個程度 になるまで等分し， $1 \mathrm{~cm}$ 四方のスライドガラスに載せ た。この正方形内の $1 \mathrm{~mm}$ 四方のマス目 (縦 10, 横 10) 内の石英粒子を右上端から 50 カウントした. 円磨度印 象図 (Krumbein, 1941) をもとに，石英粒子の多面形の 全ての頂点が角ばっている超角碟〜角砂 (円磨度 : 0.1 〜0.2)，一部の頂点が丸まっている亜角礫〜亜円礫 (円 磨度：0.3〜0.4), 全ての頂点が丸まっている円礫〜超 円碟 (円磨度：0.5〜1.0)の3つに区分した.

\section{3. 年 代}

地点 3 のトレンチ断面の砂層 (S3-1) の直上 (深度 29.5 $\sim 30 \mathrm{~cm}$ ）の砂質シルト層中から，樹木片の形状が保た れている木炭を採取し, (株) 地球科学研究所に加速器質 量分析法による ${ }^{14} \mathrm{C}$ 年代測定を依頼した．暦年較正には Oxcal 4.10 (Bronk Ramsey, 2009) を用い, 較正のた めのデータセットは IntCal09 (Reimer et al., 2009)を 使用した.

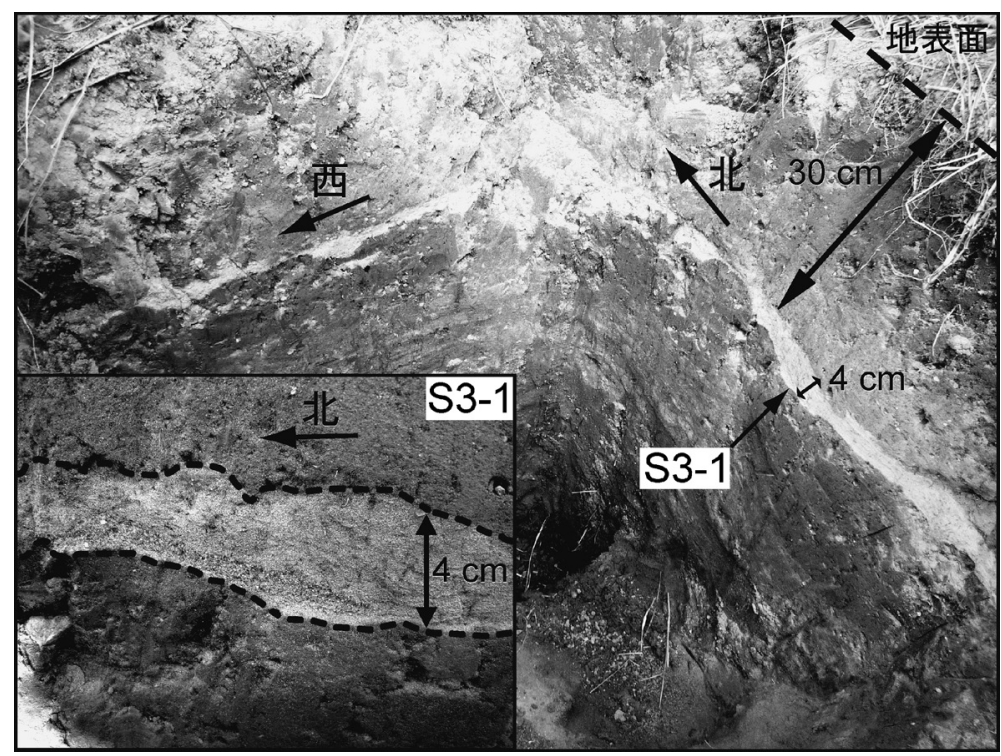

図 3 地点 3 に扔けるトレンチ断面の写真

Fig. 3 Photograph showing geological profile of the test trench at site 3 


\section{4. 歴史記 録}

田原市教育委員会 (2005) の宮本家文書「神祇最上御 神前家寶書記」と鈴木三十郎家文書「天地之間珍事変事 書留万物用心記」に記載されている, 1854 年安政東海地 震および 1707 年宝永地震に伴う調査地域周辺の津波被 害および津波挙動について, 史料分析を行った.

\section{IV. 結 果}

\section{1. 粒度分析}

(1) 篩 法

地点 1〜3の深度 $30 \mathrm{~cm}$ 付近で観察された砂層 ( $\mathrm{S} 1$ 1，S2-1，S3-1）の泥分を除いた粒度組成は細粒砂の割
合が 46.3〜 64.6\% と卓越する (図 4). 若見海岸の前 浜 (地点 5) と後浜 (地点 6) では細粒砂の割合が, 赤羽 根海岸の前浜 (地点 7) では中粒砂の割合が最も高く, 淘汰が良い. 精進川の河床堆積物 (地点 4) は, 砂層の 砂や海浜砂と比べて粗粒で淘汰が悪い.

\section{（2）沈降管法}

篩法でも確認されたように，海浜砂は淘汰が良い(淘 汰度 : 0.3 0.4). S3-1 砂層の平均粒径值と最頻値は 若見海岸の前浜砂 (地点 5) と一致するが, 中粒砂〜粗 粒砂にも比較的富み, 海浜砂と比べてやや淘汰が悪 い(淘汰度 : 0.6).

\section{2. 円磨度解析}
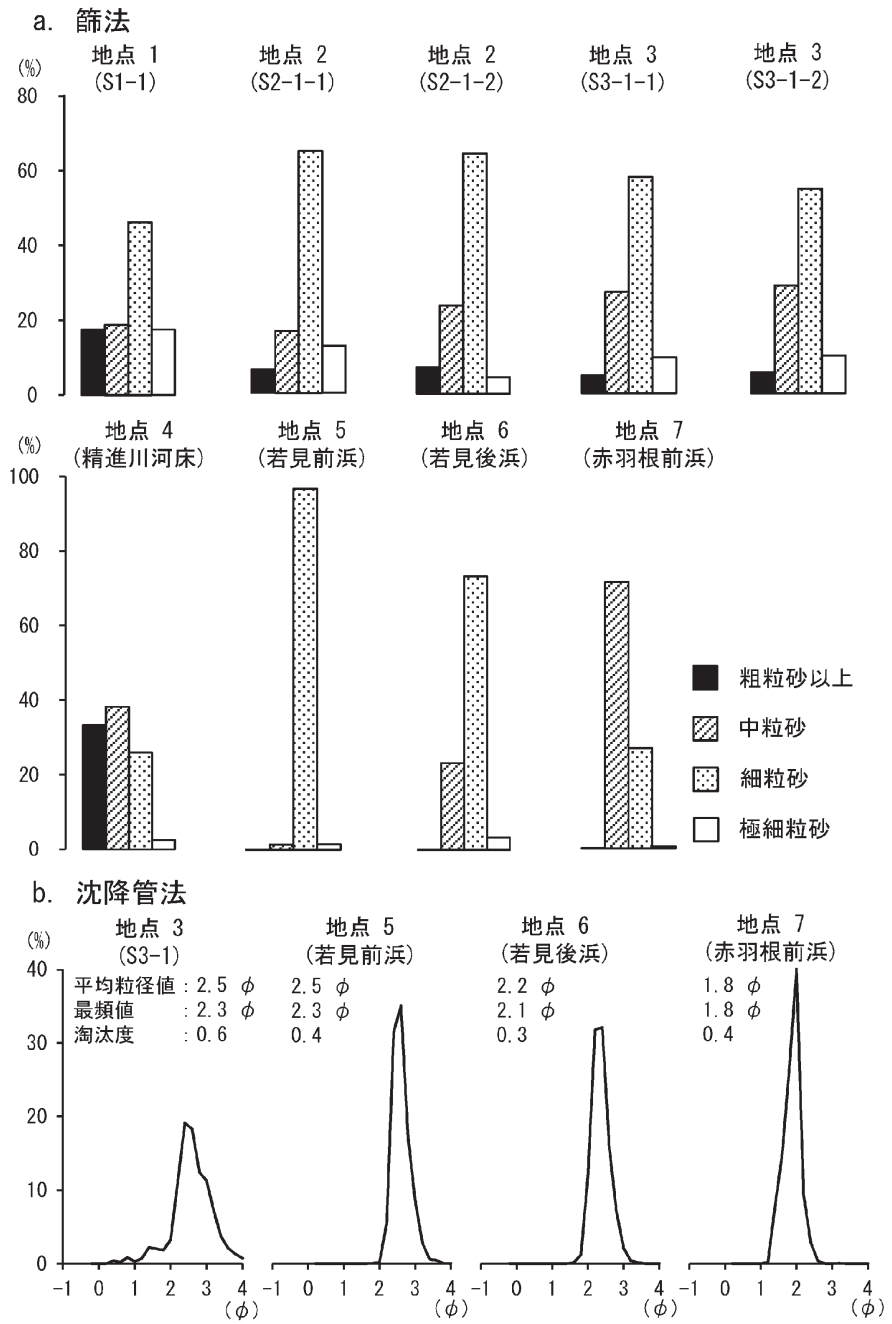

図 4 篩法と沈降管法による各地点の粒度分析結果

Fig. 4 Grain size distribution by sieving analysis and settling tube analysis 
円磨度の解析結果を図 5 に示す．精進川の河床堆積 物 (地点 4) 以外の, S2-1 砂層 (地点 2) および海浜砂 （地点 5 7) では, 円礫〜超円礫の割合が最も高い. S11 砂層と S3-1 砂層についても, S2-1 砂層と同様の傾向 であることを，顕微鏡下で確認している．また， S2-1 砂層では地点 5,6 の海浜砂よりも円礫〜超円礫の占め る割合が高い。

\section{3. 年 代}

地点 3 で観察された S3-1 砂層 (深度 30〜 34 cm) の直 上 (深度 $29.5 \sim 30 \mathrm{~cm}$ ) で採取された炭化物 (木炭) の ${ }^{14} \mathrm{C}$ 年代值は $90 \pm 40 \mathrm{yrs}$ BP で, 較正年代は AD1681 1939

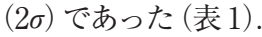

\section{4. 歴 史 記 録}

\section{（1）安政東海地震 (1854 年) による津波}

若見村八幡宮 (図 1)の神主家である宮本家の記録「神 祇最上御神前家寶書記」には，「打揚汐八池尻川当当家 浦前古田下迄打込下之内八田畑共_海=成，池尻下 ひく みの家八ゆか上迄余程汐上り」「弁天社高浪二て流失仕 候」という記載がある（田原市教育委員会, 2005)。また， 赤羽根中村の鈴木三十郎家には，この地域の災害記録を まとめた「天地之間珍事変事書留万物用心記」という記 録がある。この記録には，「池尻河分入込 : 候汐村方茂 川渡》場迄汐揚 n候」という記載がある（田原市教育委員 会，2005）。これらの記載から，津波が池尻川と精進川 の両河川を遡上し，精進川を挟んで地点 1 ～3 の対岸に 位置する池尻村の川筋の家屋に床上浸水の被害を与えた こと, 若見村八幡宮近くの水田（地点 $1 \sim 3$ 付近）まで津 波が执しよせ，弁天社 (標高約 $10 \mathrm{~m}$, 図 1) が津波によ り流出したことがわかる，飯田（1985）は，歴史記録に もとづいて，この地域での津波高を 6 10 $\mathrm{m}$ と推定し ている(表2).

\section{（2）宝永地震 $(1707$ 年)による津波}

「天地之間珍事変事書留万物用心記」には，「当所も大 地震跡大つなみ，高汐二而浜方漁具流れ候与申古人分言伝 へ二候」という記載がある（田原市教育委員会, 2005). この記載から，この地域が安政東海地震と同様に津波被 害を受けたことがわかる. 飯田 (1985) は, 歴史記録から, この地域での津波高を 6 7 $\mathrm{m}$ と推定している(表 2).

\section{V. 考察}

\section{1. 地点 $1 \sim 3$ の土地利用}

土地所有者によると, 地点 1 3の休耕田は 2006 年 までは水田として利用されていた.また, 1884 (明治 17) 年発行の地籍図, 1893 (明治 26) 年, 1947 (昭和 22) 年,
1960 (昭和 35) 年発行の地形図では水田となっており, 少なくとも 1884 年から 2006 年まで水田として利用さ れていたことになる.

\section{2. 平常時の堆積物}

地点 1 3 の深度 22〜 $24 \mathrm{~cm}$ 以深で観察される砂質シ ルト層は, 耕作土とは異なり, 地点 3 のトレンチ断面 においても人為的な混合は見られないため，耕作土では ないと推測される，また，淘汰も比較的良いため，耕作 される以前の平常時の堆積物と考えられる.

\section{3. 砂層の対比}

津波堆積物の層厚分布は，地形の局所的な凹凸の影響 を受ける (Nishimura and Miyaji, 1995). 地点 1〜3の うち, 地点 2 に見られる $\mathrm{S} 2-2$ 砂層と S2-3 砂層につい ては, それらに対比される砂層が地点 1 と地点 3 で観 察されない(図 2)。したがって, S2-2 砂層と S2-3 砂 層は地点 2 において局所的に堆積したイベント堆積物 である可能性があり，今回は議論の対象から外した。こ こでは地点 1 3の 3 地点で共通して深度 $30 \mathrm{~cm}$ 付近に 見出された砂層 $(\mathrm{S} 1-1, \mathrm{~S} 2-1, \mathrm{~S} 3-1)$ についてのみ議論 する.

\section{4. 砂層の供給源と堆積作用}

この砂層は, 細粒砂の割合が最も高く (46.3〜 64.6\%), 平均粒径值 $(2.5 \phi)$ は若見海岸の海浜 (地点 5,6$)$ の值

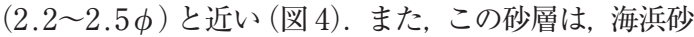
よりも円磨度が高い粒子に富む (図 5)。円磨度の高い砂 粒子は, 砂漠の風成砂や浅海砂〜海浜砂, 何度もリサイ クルされた堆積物に限られるため(公文・立石編, 1998), S2-1 砂層および若見海岸の海浜砂の解析結果は，一般 的な海浜砂の円磨度の傾向と整合的であるといえる。し たがって, 深度 $30 \mathrm{~cm}$ 付近の砂層の主な供給源は, 海 浜砂である可能性が高い.

一方，この砂層と河床堆積物（地点 4) について, 粒 度および円磨度をそれぞれ比較すると, 河床堆積物は砂 層に比べて粒度が粗く，円磨度が低いため，砂層は河川 からのみの堆積物の供給，すなわち洪水によって形成さ れた可能性は低い. 1893 (明治 26) 年当時の海岸線から 地点 1〜3 までは約 $500 \mathrm{~m}$ あり, 海浜砂を長距離運搬する ことができるのは，津波もしくは高潮だと考えられる. また, S2-1 砂層，S3-1 砂層で観察された級化構造や, S3-1 砂層で見られた明瞭な侵食基底面や平行ラミナは 津波堆積物の特徴の一つである (Morton et al., 2007).

S3-1 砂層 (深度 30 34 cm) の下部 (深度 33 34 cm) で観察されたチャート岩片の濃集層の主な構成粒子は粗 粒砂である. 粗粒砂は, 海浜砂 (地点 5〜7) にはほとん 


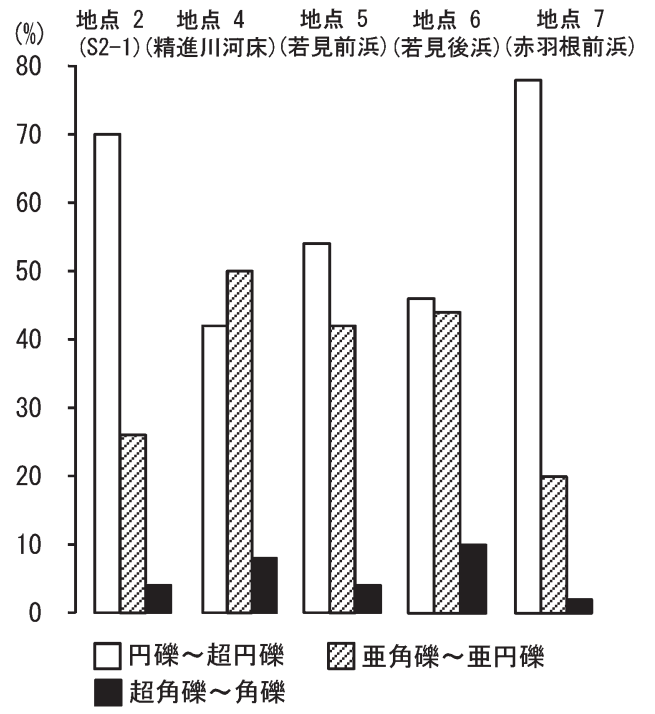

図 5 各地点の円磨度解析結果

Fig. 5 Results of roundness analysis

表 $1{ }^{14} \mathrm{C}$ 年代測定結果

Table 1 Results of radiocarbon dating

\begin{tabular}{|c|c|c|c|c|c|c|}
\hline Site & $\begin{array}{l}\text { Depth } \\
(\mathrm{cm})\end{array}$ & Material & $\begin{array}{l}\delta^{13} \mathrm{C} \\
(\%)\end{array}$ & $\begin{array}{l}{ }^{14} \mathrm{C} \text { age } \\
\text { (yrs BP) }\end{array}$ & 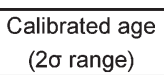 & \\
\hline 3 & $29.5-30$ & & -24.0 & $90 \pm 40$ & -193 & 303 \\
\hline
\end{tabular}

ど含まれていない，一方，精進川の河床堆積物（地点 4) は粗粒砂サイズのチャート岩片を多く含む。また，歴史 記録には, 安政東海地震に伴う津波が精進川を遡上し, 地点 1 ～付近の水田まで浸水したという記録が残って いる（田原市教育委員会, 2005)。現在, 精進川の河床 は地表面から $2 \mathrm{~m}$ 以上低いが，土地所有者への聞き取 り調査によると, 昭和中期以前は, 河川改修が行われて おらず河床面と水田との高低差は数十 $\mathrm{cm}$ 程度であっ た.したがって, S3-1砂層の主な供給源は海浜と考え られるが，下部にみられる粗粒砂は，河川を遡上した津 波により河床から削剥され掃流砂として運搬されたもの であると推定される。 この推定は, 砂層, 海浜砂, 河床 堆積物の粒度分布の比較結果とも整合的である. 砂層の 粒度分布の平均粒径值や最頻值は若見海岸の海浜砂のも のと類似しているが，一方で，海浜砂には含まれず河床 堆積物には含まれている粗粒砂以上の砂粒子が砂層には 混ざっている．すなわち，この砂層は海浜砂と河川砂が 混合したものであると考えられる.

S2-1 砂層およびS3-1 砂層には, 粒径 0.2〜2 cm の
表 2 調査地域周辺の歴史津波

Table 2 List of historical tsunamis in the study area

\begin{tabular}{cccc}
\hline 年 月 & 地震名称 & 地震規模 $(M)$ & 津波高 $(\mathrm{m})$ \\
\hline 1096年 12月17日 & 嘉保 & 8.4 & $5 \sim 7$ \\
1498年 9月20日 & 明応 & 8.6 & $5 \sim 8$ \\
1605年 2月 3日 & 慶長 & 7.9 & $5 \sim 6$ \\
1707年 10月28日 & 宝永 & 8.4 & $6 \sim 7$ \\
1854年 12月23日 & 安政東海 & 8.4 & $6 \sim 10$ \\
1944年 12月 7日 & 昭和 & 8.0 & 1.5 \\
\hline
\end{tabular}

年月日は，新暦で表記.

飯田（1985）をもとに作成.

チャートおよび泥岩の亜角礫〜円碟が含まれる，精進川 下流域の河床～河口に分布している礫は，これらの砂と 類似した岩種と形状を示す。また，砂層中の礫の表面は 新鮮であり, 表面が風化している福江面の段丘構成層中 の礫とは異なる. 地点 1 ～3 周辺には段丘崖がないこ とからも，これらの砂は河床由来であることが推定され る.

粒径 $0.2 \sim 2 \mathrm{~cm}$ の礫が河床から移動を開始するため には, 約 $0.6 \sim 2 \mathrm{~m} / \mathrm{s}$ 以上の流速の水流が必要であると 考えられるため (Sundborg, 1956), 津波と高潮の遡上 速度を比較する．遡上速度は，一般に津波の方が大きい とされている (Nott, 2003 ; Morton et al., 2007). 津波 の河川遡上速度は, 日本海中部地震津波 (1983 年) や東 北地方太平洋沖地震津波 (2011 年) において, 実測值で それぞれ $2.7 \mathrm{~m} / \mathrm{s}, 7.6 \sim 8.2 \mathrm{~m} / \mathrm{s}$ という報告がある(岩 崎ほか, 1984 ; 国土技術研究センター, 2011). 一方, 高潮の河川遡上速度は, 実測值の報告はなく, 原ほか (2009) の数值計算結果では, $0.5 \mathrm{~m} / \mathrm{s}$ 以下とされてお り，一般に津波に比べてかなり小さいと考えられる。 ま た, 高潮は気圧の低下に伴うゆっくりとした水位上昇に よって引き起こされるため, 内陸方向への河川遡上速度 は小さくなると考えられる. したがって, 高潮による河 川遡上では, 河床礫が内陸方向に運搬されるほどの流速 が発生する可能性は低い，そのため, 砂層中への河床砂 の混在は, 津波による運搬作用を示唆している可能性が 高い.

津波が河川を遡上することで，海浜や砂丘だけではな く河床からも堆積物が供給されることは, 北海道南西沖 地震津波 (1993 年)による堆積物においても報告されて いる (Nanayama and Shigeno, 2006)。このような海 浜砂と河川砂の混合は, 河川遡上後に汇濫した津波特有 の堆積過程であると考えられる.

なお, 池尻川・精進川河口沖の浅海底 (水深 $15 \mathrm{~m}$ 付 
近)にも粗粒砂サイズ以上の砂粒子 (中央粒径值 : -0.3 ф) が含まれている (国土地理院, 1974).ただし, 従来の 多数の水路実験や数值計算, 現地観測の結果から, 粒径 が大きいほど浮遊形式ではなく掃流形式での運搬が卓越 することや，流れ内部における浮遊砂濃度の鉛直分布は 基準面から上方に向かって指数関数的に小さくなること が示されている(例えば, Nielsen, 1986 ; 柴山・Winyu, 1993 ; Nishi et al. 1994 ; 福田ほか, 2006). したがっ て, 粗粒砂サイズ以上の砂粒子が浅海底から浮遊砂とし て巻き上げられ, 海岸線から約 $500 \mathrm{~m}$ 内陸の地点まで 運搬された可能性は低い。

S2-1 砂層およびS3-1 砂層は単層内で正級化してい る. 級化構造は, 堆積過程中の時間的に継続した水流力 の減少を示している (Goff et al., 2012). 津波と高潮の 周期は，それぞれ 100〜2,000 秒，10〜25秒程度と考え られており (Morton et al., 2007)，津波の周期は高潮 に比べて非常に長いと言える. 実際に Goff et al. (2012) などでは, 級化構造は津波堆積物において一般的に観察 されるとしている. 宮本家文書 (田原市教育委員会, 2005) には, 安政東海地震津波 (1854 年) によって, 地点 1 ～ 周辺の田畑が海になったという記述があり，この津波で は，時間的に継続した水流による堆積作用が考えられ る.したがって, この砂層は, 高潮堆積物より, 津波堆 積物の可能性が高いと結論づけられる。

\section{5. 砂層の堆積年代}

地点 1 3 の深度 $30 \mathrm{~cm}$ 付近で観察された砂層の堆積 年代を考察する. ${ }^{14} \mathrm{C}$ 年代測定 (較正年代 : $\mathrm{AD} 1681$ 1939）を行った木炭は, 樹木片の形状を残し比較的新鮮 な形状を呈していたので，樹木が木片となった後，比較 的短時間で埋積された可能性が高い.また，S3-1 砂層 直上に存在しており, 砂層と木片の堆積時期には大きな 時間間隙 (約 100 年以上) はなかったと考えられる．以 上のことから，この砂層の堆積年代は AD1600 年以降 である可能性が高い，さらに，地形図や地籍図にもとづ く水田としての利用年代 (AD1884～2006) を考慮する と，遅くとも AD1884 年にはこの場所は水田になって いたことになり，砂層の堆積はそれ以前であると考えら れる. したがって, 砂層の堆積年代は AD1600 年頃か ら 1884 年頃と推定される.

この期間に渥美半島の太平洋岸に被害を与えた歴史津 波として, 田原市教育委員会 (2005) などの歴史史料抒 よび本地域の歴史地震・津波に関する既存研究 (飯田, 1985 ; 清田, 2003 ; 藤城, 2008 ; 東三河地域防災研究協 議会, 2012) には, 慶長地震 (1605 年), 宝永地震 (1707
年), 安政東海地震 (1854 年) が示されており, 砂層は これらの地震のいずれかに伴う津波で形成されたものと 考えられる。

本地域では, 慶長地震 (1605 年) および宝永地震 (1707 年)に伴う津波の挙動に関する歴史記録は少なく，歴史 記録と堆積物記録がそれぞれ示している津波の挙動との 対比は難しい。 ただし，安政東海地震 (1854 年)による 津波に関する歴史記録 (田原市教育委員会, 2005) には, この津波の挙動に関する記載が残されている。この内容 から, 安政東海地震発生時に, 河川を遡上した津波が汇 濫したことや，時間的に継続した流れがあったことが推 測される.このような歴史記録に残された津波の挙動 と, 海浜砂と河川砂の混合や級化構造という堆積物に保 存された津波の挙動は対比可能であると思われる.

\section{VI. おわりに}

愛知県渥美半島太平洋岸の沿岸低地で, 地表面下 $1 \mathrm{~m}$ 以内に, 平常時の堆積物とは異なる特徴を持つ複数の砂 層が見られた。 これらの砂層のうち, 複数の地点で見出 された深度 $30 \mathrm{~cm}$ 付近の層厚 1 $4 \mathrm{~cm}$ の砂層について, 堆積学的な解析を実施した結果, 以下の 2 点が明らか になった。

（1）粒度分析，円磨度解析から，この砂層の主な供給 源は海浜であることが示唆された

(2) 海浜砂の運搬距離，海浜砂と河川砂の混合，津波 と高潮の水理学的特徵の違いなどを考慮すると, この砂 層は津波により海浜および河床の砂が運搬されて沿岸低 地上に堆積したものと推定される。

さらに, ${ }^{14} \mathrm{C}$ 年代扔よび歴史記録の記述との整合性を 考慮すると, この砂層は江戸時代の歴史地震に伴う津波 堆積物の可能性が高い. 歴史記録に残された津波の挙動 を堆積物記録から検証するなど，歴史記録と堆積物記 録，それぞれが持つ古津波に関する情報を相互補完して いくことは, 古津波の挙動や規模の復元精度や古津波研 究に対する信頼性の向上につながるだろう.

謝辞 本稿は，2009 年度に首都大学東京都市環境学 部地理環境コースに提出した卒業論文に加筆・修正した ものである. 同大学の地理環境コース地形・地質学研究 室の山崎晴雄先生，鈴木敦彦先生や学生の方々には，有 益な議論をして頂き，現地調査に同行して頂いた．田原 市の鬼落とし会の菊池辰夫氏には, 歴史史料を提供して 頂いた．田原市和地小学校の藤城信幸先生には，現地調 査に同行して頂き，調查地域の地形・地質や歴史津波に 
ついてご助言を頂いた．田原市の石井一希氏には，歴史 記録についてご助言を頂いた. 奈良大学の海津正倫先 生, 名古屋大学の鈴木康弘先生, 堀 和明先生には, 多 くのご指導を頂いた，京都大学の成瀬 元先生には, 沈 降管の使用に際してお世話になり, 有益な議論をさせて 頂いた，以上の方々に媣く謝意を表します。

\section{引用 文 献}

Bronk Ramsey, C. (2009) Bayesian analysis of radiocarbon dates. Radiocarbon, 51, 337-360.

藤野滋弘 - 小松原純子 - 宍倉正展 - 木村治夫 - 行谷佑一 （2008）志摩半島におけるハンドコアラーを用いた古 津波堆積物調查報告. 活断層・古地震研究報告, 8, 255-265.

藤城信幸（2008）渥美半島の表浜集落における宝永地 震の被害状況と海食崖との関係. 田原市博物館研究紀 要, $3,70-89$.

福田裕司・後藤和久 - 今村文彦・越村俊一 (2006) 津 波による土砂移動の水理実験と数值解析の現状. 月刊 地球, 28, 563-567.

Goff, J., Chagué-Goff, C., Nichol, S., Jaffe, B.E. and Dominey-Howes, D. (2012) Progress in palaeotsunami research. Sedimentary Geology, 243-244, 70-88.

原 信彦・山田 正・柴木秀之（2009）一般座標系に よる河川分流を考慮した高潮・洪水同時生起の数值シ ミュレーション. 土木学会論文集 B2 (海岸工学), B2-65, 246-250.

東三河地域防災研究協議会 (2012) 東三河津波歴史調 查研究業務報告書, $85 \mathrm{p}$, 東三河地域防災研究協議会.

飯田汲事（1985）東海地方地震 - 津波災害史. 800 p, 愛知工業大学工学部.

岩崎敏夫 ·中村武弘・伊藤 驍（1984）日本海中部地 震における津波災害の特性. 東北大学工学部津波防災 実験所研究報告, 1, 1-11.

清田 治（2003）渥美半島における嘉永東海地震の実 状一現存する災害記録から一. 渥美町郷土資料館研究 紀要, 7, 29-60.

国土地理院（1974）沿岸海域土地条件図「伊良湖岬」.

国土技術研究センター (2011) 第 2 回東北地方太平洋 沖地震を踏まえた河口堰・水門等技術検討委員会. http://www.jice.or.jp/sonota/t1/201106150.html, 2012 年 9 月 1 日引用.

Komatsubara, J. and Fujiwara, O. (2007) Overview of Holocene tsunami deposits along the Nankai, Suruga, and Sagami Troughs, Southwest Japan. Pure and Applied Geophysics, 164, 493-507. 小松原純子・岡村行信 (2007) 三重県志島低地におけ る津波堆積物調查 (予察). 活断層・古地震研究報告, 7, 209-217.

小松原純子・藤原 治・鎌滝孝信（2006a）南海・駿河 および相模トラフ沿岸域における津波堆積物。歴史地 震, 21，93-109.

小松原純子・藤原 治 - 高田圭太・澤井祐紀・タン・ ティン・アォン・鎌滝孝信（2006b）沿岸低地堆積物 に記録された歴史時代の津波と高潮：南海トラフ沿岸 の例．活断層・古地震研究報告, 6, 107-122.

Komatsubara, J., Fujiwara, O., Takada, K., Sawai, Y., Aung, T.T. and Kamataki, T. (2008) Historical tsunamis and storms recorded in a coastal lowland, Shizuoka Prefecture, along the Pacific Coast of Japan. Sedimentology, 55, 1703-1716.

Krumbein, W.C. (1941) Measurement and geological significance of shape and roundness of sedimentary particles. Journal of Sedimentary Petrology, 11, 64-72.

熊谷博之（1999）浜名湖周辺での東海沖の大地震に伴 う津波堆積物の調查. 地学雑誌, 108, 424-432.

公文富士夫 ·立石雅昭編 (1998) 新版 砕屑物の研究法. 399 , 地学団体研究会.

Morton, R.A., Gelfenbaum, G. and Jaffe, B.E. (2007) Physical criteria for distinguishing sandy tsunami and storm deposits using modern examples. Sedimentary Geology, 200, 184-207.

Nanayama, F. and Shigeno, K. (2006) Inflow and outflow facies from the 1993 tsunami in southwest Hokkaido. Sedimentary Geology, 187, 139-158.

成瀬 元 (2005) 沈降管天秤法粒度分析用アプリケー ション“STube” の特色と利用法. 堆積学研究, 62, 5561.

Nielsen, P. (1986) Suspended sediment concentrations under waves. Coastal Engineering, 10, 23-31.

Nishi, R., Sato, M. and Nakamura, K. (1994) Grainsize distribution of suspended sediments. Proceeding of the 23rd International Conference on Coastal Engineering, ASCE, 2293-2306.

Nishimura, Y. and Miyaji, N. (1995) Tsunami deposits from the 1993 Southwest Hokkaido Earthquake 
and the 1640 Hokkaido Komagatake Eruption, Northern Japan. Pure and Applied Geophysics, 144, 719-733.

Nott, J. (2003) Tsunami or storm waves? - Determining the origin of spectacular field of wave emplaced boulders using numerical storm surge and wave models and hydrodynamic transport equations. Journal of Coastal Research, 19, 348356.

Reimer, P.J., Baillie, M.G.L., Bard, E., Bayliss, A., Beck, J.W., Blackwell, P.G., Bronk Ramsey, C., Buck, C.E., Burr, G.S., Edwards, R.L., Friedrich, M., Grootes, P.M., Guilderson, T.P., Hajdas, I., Heaton, T.J., Hogg, A.G., Hughen, K.A., Kaiser, K.F., Kromer, B., McCormac, F.G., Manning, S.W., Reimer, R.W., Richards, D.A., Southon, J.R., Talamo, S., Turney, C.S.M., van der Plicht, J. and Weyhenmeyer, C.E. (2009) IntCal09 and Marine09 radiocarbon age calibration curves, $0-50,000$ years cal BP. Radiocarbon, 51, 1111-1150.

柴山知也・Winyu, R.（1993）砕波帯を含吉浮遊砂濃度 の鉛直分布の評価. 海岸工学論文集, 40, 306-310.

杉山雄一（1991）渥美半島-浜名湖東岸地域の中部更新 統一海進-海退堆積サイクルとその広域対比一. 地質 調查所月報，42，75-109.

Sundborg, B.W. (1956) The River Klaralven, a study of fluvial processes. Geografiska Annarler, 38, 127-316.

田原市教育委員会（2005）赤羽根の古文書一近世資料 編一. $908 \mathrm{p}$, 愛知県田原市教育委員会.

高田圭太 - 佐竹健治 - 寒川 旭 - 下川浩一 - 熊谷博之 . 後藤健一・原口 強 (2002) 静岡県西部湖西市にお ける遠州灘沿岸低地の津波堆積物調查（速報）。活断 層・古地震研究報告, 2, 235-243.

宇佐美龍夫（2003）最新版日本被害地震総覧. 645 p, 東京大学出版会.

渡辺偉夫（1998）日本被害津波総覧第二版. $238 \mathrm{p}$, 東 京大学出版会.

\title{
Event deposits correlated with a historical tsunami in the Edo period, on the coastal lowland of the Atsumi Peninsula, central Japan
}

\author{
Tomoya Abe ${ }^{* 1, a}$ and Masaaki Shirai* ${ }^{2}$
}

The Pacific coast of Atsumi Peninsula has been repeatedly damaged by tsunamis. The characteristics of event deposits in the coastal lowland are discussed based on sedimentological and historical records. Sand layers, $1-4 \mathrm{~cm}$ thick, were found approximately $30 \mathrm{~cm}$ below the surface in three sediment cores and a test trench. Grain size analysis by sieving and settling tube methods and roundness analysis suggest that sand grains of the sand layer were originated mainly from beaches. On the basis of the inland sediment-transport distance, radiocarbon age, mixing of beach-sand and river-sand, and historical records, it was estimated that the sand layers were formed by the inundation process of a historical tsunami in the Edo period.

Keywords : tsunami deposit, grain size analysis, roundness analysis, historical record

*1 Department of Geography, Graduate School of Environmental Studies, Nagoya University. Furocho, Chikusaku, Nagoya, 464-8601, Japan.

*2 Department of Geography, Graduate School of Urban Environmental Sciences, Tokyo Metropolitan University. 1-1 Minami-ohsawa, Hachioji, 192-0397, Japan.

*a Corresponding author : abe.tomoya@a.mbox.nagoya-u.ac.jp 